This is a self-archived version of an original article. This version may differ from the original in pagination and typographic details.

Author(s): Kautonen, Maria

Title: Om hur finskspråkiga och svenskspråkiga lyssnare bedömer och värderar avancerade talares uttal av finlandssvenska

Year: 2018

Version: Accepted version (Final draft)

Copyright: (c) Universitetsforlaget AS, Scandinavian University Press, 2018.

Rights: In Copyright

Rights url: http://rightsstatements.org/page/InC/1.0/?language=en

Please cite the original version:

Kautonen, M. (2018). Om hur finskspråkiga och svenskspråkiga lyssnare bedömer och värderar avancerade talares uttal av finlandssvenska. Nordand : nordisk tidsskrift for andrespråksforskning, 2(2), 131-150. https://doi.org/10.18261/issn.2535-3381-2018-02-02 


\section{Om hur finskspråkiga och svenskspråkiga lyssnare bedömer och värderar avancerade talares uttal av finlandssvenska}

\section{Sammandrag}

Syftet med denna studie är att analysera avancerade finskspråkiga inlärares uttal av finlandssvenska i fritt tal: vilka är de svåraste inlärningsmålen i S2-uttal (andra- och främmande språk) och hurdana skillnader finns det mellan talare på olika färdighetsnivåer? Därtill undersöks om finskspråkiga lyssnare värderar uttalet på samma sätt som svenskspråkiga lyssnare. S2-talarnas prestationer i en monologuppgift värderas av finskspråkiga och svenskspråkiga lyssnare gällande hur bra talarna kan segment och prosodi i finlandssvenska.

Forskning i finskspråkiga talares S2-uttal av finlandssvenska ger oss ett speciellt perspektiv på S2uttalsinlärning. Eftersom språken liknar varandra fonetiskt bör svårigheterna inte vara alltför stora och inlärningen av ett inföddliknande uttal kan anses vara ett realistiskt mål. Uttalet sägs ju vara ett av de svåraste inlärningsmålen i S2 särskilt om inlärningen inte påbörjats mycket tidigt.

Resultaten visar att S2-uttalet präglas av segmentella och prosodiska avvikelser även på de högsta färdighetsnivåerna. Skillnaderna mellan färdighetsnivåerna är störst $\mathrm{i}$ segment och satsprosodi. De svenskspråkiga lyssnarna är striktare i sina värderingar än de finskspråkiga lyssnarna. Utöver det teoretiska värdet för S2-uttalsinlärningsmodellerna kan resultaten utnyttjas i språkundervisning och i värdering av muntliga språkfärdigheter.

Nyckelord: avancerade inlärare, finlandssvenska, S2-uttal, värdering av uttal

How Finnish-speaking and Swedish-speaking listeners assess advanced speakers' pronunciation of Finland-Swedish

\section{Abstract}

This study examines advanced Finnish-speaking learners' pronunciation of Finland-Swedish in free speech: what are the greatest difficulties in L2 (second and foreign language) pronunciation and how do speakers on different proficiency levels differ? Furthermore, it is of interest whether Finnish-speaking and Swedish-speaking listeners differ as pronunciation raters. The L2 speakers' pronunciation in a monologue task is assessed by Finnish-speaking and Swedish-speaking listeners regarding segmental and suprasegmental features.

Research on Finnish-speakers' L2 pronunciation of Finland-Swedish gives us an interesting perspective on L2 pronunciation learning. Because the languages are phonetically similar, there should be no major difficulties and learning of a native-like pronunciation can be considered a realistic goal. Pronunciation is, however, regarded as one of the most difficult areas in L2 learning, particularly if learning has not been started at an early stage.

Results show that $\mathrm{L} 2$ pronunciation is characterized by deviations in segments and prosody even on the highest proficiency levels. Differences between the proficiency levels are greatest for segments and sentence prosody. Swedish-speaking listeners give stricter ratings than Finnish-speaking listeners. Besides the theoretical value for L2 pronunciation learning models, the results also benefit language teaching and oral language skills assessment.

Key words: advanced learners, Finland-Swedish, L2 pronunciation, pronunciation rating 


\section{Inledning}

Språkinläraren ställs inför flera utmaningar vid inlärning av andraspråk och främmande språk (S2). Uttalet har påståtts vara ett av de svåraste inlärningsmålen särskilt om inlärningen inte påbörjats före puberteten (jfr Lenneberg, 1967; Scovel, 1969, 2000; se dock Flege, 1987; Piske m.fl., 2001; Moyer, 2013 om andra faktorer som kan vara av stor betydelse för inlärningen). Forskningen pekar på att även om en del talare kan tillägna sig ett inföddlikt uttal har också mycket avancerade S2-talare ofta några målspråksavvikelser i uttalet trots att de i övrigt behärskar S2-språket inföddlikt (t.ex. Bongaerts m.fl., 1997; Angelovska, 2012). Genom att studera avancerade språkinlärares uttal får vi ny kunskap om de mest bestående svårigheterna vid inlärningen av S2-uttal. Denna kunskap tjänar också bedömning av språkfärdighet. När S2-talarnas uttal jämförs med deras allmänna nivå av muntlig språkfärdighet får vi också en inblick i hur uttal och muntlig färdighet hänger ihop: är uttalet helt målspråkslikt på de högsta färdighetsnivåerna av muntlig kommunikation och i vilka aspekter är uttalet målspråkslikt i så fall?

I denna studie studeras avancerade inlärares S2-uttal hos finskspråkiga inlärare av finlandssvenska. Forskning i finskspråkiga talares uttal av finlandssvenska ger oss ett speciellt perspektiv på S2uttalsinlärningen. Finlandssvenska är den varietet av svenska som ca $5 \%$ av befolkningen talar som förstaspråk i Finland (FOS 2015). Varieteten skiljer sig från sverigesvenska framför allt vad gäller uttalet. På grund av rytmiska drag, avsaknad av ordaccentdistinktionen och annorlunda kvantitetsmönster (till exempel s.k. kortstavighet) liknar finlandssvenska i vissa prosodiska avseenden mer finska än sverigesvenska (Kuronen \& Leinonen, 2001; Reuter, 2015). En jämförelse mellan finlandssvenskt och finskt uttal uppvisar också andra likheter (se t.ex. Suomi m.fl., 2008; Kuronen \& Leinonen, 2010); finlandssvenska och finska har båda generellt fallande intonation och satsbetoning markeras både med intonation och med intensitet. Därtill har vokalsystemen många likheter med finlandssvenskans nio, /i, $y$, $\forall, e, \emptyset, æ, a, o, u /{ }^{1}$, och finskans åtta fonem, /i, y, e, $\varnothing, æ, a, 0, u /$. Utöver de 13-17 konsonantfonem som finns i finska, /p, t, k, d, m, n, y, l, r, s, h, v, j/ samt möjligen /b, g, f, s/ (jfr Suomi m.fl. 2008), har finlandssvenska ytterligare två konsonanter, /tf, dj/. Till följd av likheterna bör svårigheterna baserat på kontrastiv analys inte vara alltför stora (jfr Lado, 1957) och inlärning av ett inföddliknande uttal kan kanske anses vara ett realistiskt mål för inlärargruppen. Finskspråkiga talares uttal av finlandssvenska har kartlagts på de lägre och mellersta färdighetsnivåerna av den europeiska referensramen (CEFR; Europarådet, 2001) i tidigare studier (Kautonen, 2016, 2017). Syftet med föreliggande studie är att komplettera bilden genom att undersöka de högsta nivåerna B2, C1 och C2, och besvara följande forskningsfrågor:

(i) Hurdana uttalssvårigheter har avancerade finskspråkiga inlärare i S2-finlandssvenska i fritt tal enligt halvprofessionella lyssnare?

(ii) Hurdana skillnader finns det mellan inlärarna på färdighetsnivåerna B2-C2 enligt halvprofessionella lyssnare?

(iii) Värderar finskspråkiga och svenskspråkiga lyssnare S2-uttalet på samma sätt? Om inte, hurdana skillnader finns det mellan de två lyssnargrupperna?

Studien bidrar till diskussionen om hur lyssnarens förstaspråk (S1) påverkar värdering av uttalet genom att visa om infödda och icke-infödda talare värderar uttalet på samma sätt. Tidigare studier har visat

\footnotetext{
${ }^{1}$ I artikeln anges fonem mellan snedstreck och allofoner inom hakparentes.
} 
belägg både för och emot att lyssnarens S1 kan påverka bedömningen. Crowther m.fl. (2016) fann inga skillnader mellan infödda och icke-infödda lyssnare vid värdering av begriplighet och främmande accent $\mathrm{i}$ fransk S2-engelska. I Fayer och Krasinskis (1987) och Koster och Koets (1993) studier var icke-infödda lyssnare däremot striktare än infödda lyssnare mot avvikelser i S2-engelska (se också Wrembel, 2010). Finskspråkiga och engelskspråkiga lyssnare reagerade inte heller på samma sätt på finsk S2-engelska i Morris-Wilsons studie (1999). Just finskspråkiga och svenskspråkiga lyssnares upplevelser av målspråksavvikelserna är ett viktigt forskningsobjekt, eftersom S2-uttalet i finlandssvenska oftast bedöms av dessa två talargrupper i skolundervisningen i Finland (se Korkman m.fl. 2010: 64 och LehtiEklund \& Green-Vänttinen, 2011 om att svensklärarna ofta använder finska i klassrummet och har själva finlandssvenskt uttal). I klassrummen har bedömarna (=lärarna) alltså ofta samma S1 som språkinlärarna, och om detta påverkar bedömningen är därför viktigt att studera.

\section{Uttalsinlärningen: Avancerade inlärare och finskspråkiga inlärare av finlandssvenska}

Teorin om en kritisk ålder för inlärning av S2-uttal (Lenneberg, 1967; Scovel, 1969) har bidragit till stort intresse för forskning i avancerade inlärares uttal. Även om vissa studier tyder på att ett inföddlikt uttal är ett möjligt inlärningsmål (t.ex. Angelovska, 2012), visar ett antal studier att det ofta förekommer svårigheter både på segmentell och prosodisk nivå även hos avancerade inlärare av olika målspråk.

På segmentell nivå tycks uttalssvårigheterna ofta härstamma från skillnaderna mellan S1 och S2. Det finns nya ljud som antingen saknas i inlärarens S1 eller uttalas på ett annorlunda sätt i S2 (jfr kontrastiv analys; Lado, 1957). Dessa antas vara svåra p.g.a. att språkinläraren har svårigheter med att höra skillnaden mellan det nya ljudet och S1-ljud (jfr SLM, Speech Learning Model; Flege, 1995; PAM, Perceptual Assimilation Model; Best, 1995). Fonetiskt svåra eller typologiskt ovanliga ljud (jfr markerade ljud; MDH-teorin, Markedness Differential Hypothesis; Eckman, 1977) medför också svårigheter. Tidigare studier om avancerade inlärares uttal visar stöd åt dessa teorier. I Kuronens (2016a) studie hade avancerade finskspråkiga inlärare målspråksavvikelser bl.a. i de sverigesvenska segment som saknas i

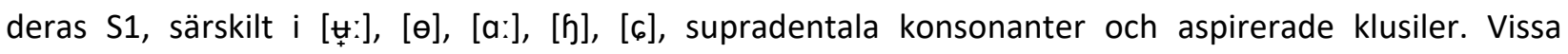
segmentella - närmast allofoniska - avvikelser förekom också i mycket avancerade eller tvåspråkiga inlärares finska (Kuronen, 2016b).

Medan segmentella avvikelser tycks vara relativt språkspecifika, verkar prosodiska svårigheter vara mer språkoberoende och likna varandra oavsett S1-S2-förhållandet. Prosodiska svårigheter kan återspegla andra aspekter av språkinlärning, bl.a. talplanering och brister i ordförråd och grammatik. Vad gäller prosodin tillhör intonation och tonaccenter de svåraste inlärningsmålen vid S2-uttalsinlärning. Rasier och Hiligsmann (2007: 47-48) anger att också mycket avancerade språkinlärare kan överdriva melodisk variation i talet. I Mennens (1998) studie misslyckades avancerade nederländska talare av nygrekiska med att tillägna sig inföddlik intonation då talarna placerade intonationstoppar för tidigt och hade för litet röstomfång. Också i Ullakonojas (2007) studie hade finskspråkiga inlärare mindre röstomfång i S2ryska än infödda talare. Därtill har inlärningen av de svenska tonaccenterna visat sig vara ett mycket krävande inlärningsmål för finskspråkiga inlärare (Kuronen, 2015, Kuronen m.fl., 2016). I Kuronens (2016b) studie om avancerade finlandssvenska talares uttal av finska var problemen i huvudsak prosodiska; S2-talarna hade problem med stavelselängderna och intonationen i långa ord samt något lägre taltempo än S1-talarna. I övrigt ansågs talarnas uttal vara målspråkligt eller åtminstone mycket nära målspråket. 
Kontrastiv analys förutser relativt bra de svårigheter som finskspråkiga talare har med segment i finlandssvenska; just de ljud som saknas i inlärares S1 orsakar svårigheter, nämligen [J] och [t $f$ ], [ $\mathrm{t}]$, allofonen [œ] och stämtonen i klusilerna [b], [d], [g] (Nygård, 1977; Hildén, 2000; Kautonen, 2016). Därtill förekommer det sammanblandning av vokalerna [u] och [o] samt [e] och [æ], vilket var mycket vanligt i Kautonens (2016) studie på de lägre färdighetsnivå i muntlig framställning (A1-B1, Europarådet, 2001). MDH-teorin (Eckman, 1977) förklarar delvis svårigheterna, bl.a. varför de markerade tonande klusilerna är svårare för finskspråkiga talare än de tonlösa. I formell språkundervisning i Finland har skriftliga färdigheter traditionellt spelat en stor roll och därför kan också ortografi påverka segmentuttalet, t.ex. vad gäller sammanblandning av vissa vokaler (jfr Peltola m.fl., 2015).

Finskspråkiga talare verkar ha mer problem med prosodi än med segment i finlandssvenska. Pausering, intonation, satsbetoning och rytm vållar mest svårigheter (Kautonen 2016). Finskspråkiga talare har liknande intonationskonturer som infödda talare av finlandssvenska, men också avvikande inlärarintonation med omotiverade meloditoppar och för stor f0-variation förekommer (Kautonen 2017). Hildén (2000) nämner vidare att finskspråkiga talare har svårigheter med segmentlängder, ord- och satsbetoning, medan i Kautonens (2016) studie var segmentlängder och ordbetoning relativt ofta korrekta. Eftersom prosodin uppvisar tydliga likheter mellan finlandssvenska och finska (se kapitel 1 samt Kuronen \& Leinonen, 2001; Reuter, 2015), förklaras svårigheterna inte enbart av skillnaderna mellan S1 och S2. Uttalet hos avancerade finskspråkiga inlärare av finlandssvenska och de mest bestående uttalssvårigheterna har dock varit outforskade hittills (Kautonen m.fl. 2016).

\section{Talarna och talmaterialet}

Som forskningsmaterial i denna studie används språktestprestationer i de allmänna språkexamina i Finland (s.k. YKI-test, www.jyu.fi/yki). S2-talarna ( $n=12)$ har tilldelats färdighetsnivåer 4-6 i muntlig framställning som motsvarar nivåerna B2-C2 i den europeiska referensramen (Europarådet, 2001). Varje nivå representeras av fyra talare. Talarna har valts med följande kriterier: de har finska som S1, de har tilldelats färdighetsnivån B2-C2 både i den valda testuppgiften och själva testet, och deras uttal ligger närmare finlandssvenska än sverigesvenska (värderat av mig och en annan forskare i projektet FOKUS ${ }^{2}$ ). Talarna är 27-49 år gamla, och det finns både kvinnor och män bland dem (9 kvinnor, 3 män). Alla talare har studerat svenska åtminstone i 4-6 år på olika utbildningsnivåer. Ljudkvaliteten i testmaterialet var tillräckligt bra för att inspelningarna kunde användas i lyssningstestet. Talarna presenteras i tabell 1.

Tabell 1. S2-talarna i studien.

\begin{tabular}{|c|c|c|}
\hline Talarkod & Kön & $\begin{array}{c}\text { Färdighetsnivå i monologen i de } \\
\text { allmänna språkexamina / i CEFR }\end{array}$ \\
\hline Talare 1 & $\mathrm{K}$ & 4/B2 \\
Talare 2 & $\mathrm{K}$ & 4/B2 \\
Talare 3 & $\mathrm{K}$ & 4/B2 \\
Talare 4 & $\mathrm{M}$ & 4/B2 \\
Talare 5 & $\mathrm{K}$ & 5/C1 \\
Talare 6 & $\mathrm{K}$ & 5/C1 \\
\hline
\end{tabular}

${ }^{2}$ Närmare om projektet, se Kautonen m.fl., 2015. 


\begin{tabular}{|c|c|c|}
\hline Talare 7 & $\mathrm{M}$ & $5 / \mathrm{C} 1$ \\
Talare 8 & $\mathrm{M}$ & $5 / \mathrm{C} 1$ \\
Talare 9 & $\mathrm{~K}$ & $6 / \mathrm{C} 2$ \\
Talare 10 & $\mathrm{~K}$ & $6 / \mathrm{C} 2$ \\
Talare 11 & $\mathrm{~K}$ & $6 / \mathrm{C} 2$ \\
Talare 12 & $\mathrm{~K}$ & $6 / \mathrm{C} 2$ \\
\hline
\end{tabular}

Taluppgiften i studien var att tala fritt $\mathrm{i}$ två minuter om ett givet tema efter ett par minuters förberedelsetid. Till analys valdes ett klipp på en minut i mitten av prestationen. Ett talprov på en minut ger en relativt bra bild av talarens färdigheter, och med denna längd på talprov blev lyssningstestet inte för arbetsamt för lyssnarna. Även kortare talprov har använts vid värdering av uttal, men då har det ofta varit fråga om värdering av inföddlikhet eller förståelighet (se Jesney, 2004). Även mycket korta klipp kan ge tillförlitliga resultat om talarens inföddlikhet (Flege, 1984), men ett kort talprov räcker inte till för att få en mer detaljerad bild av talarens uttalsfärdigheter.

Uttal tillhör värderingskriterierna i muntlig framställning i de allmänna språkexamina i Finland. På de tre högsta nivåerna gäller uttalskriterierna först och främst intonation och satsbetoning. På nivån fyra (B2 i CEFR) ska talarna ha tillägnat sig ett tydligt uttal och intonation fast det finns brister $i$ uttalet, och på nivåerna 5-6 (C1-C2 i CEFR) kan talaren variera intonation och placera satsbetoning korrekt för att uttrycka finare betydelsenyanser (min egen översättning, Allmänna språkexamina, 2016). Det nämns också på nivån 6 att icke-målspråksliga drag, såsom främmande accent, förekommer enbart sporadiskt $i$ talet (min egen översättning, Allmänna språkexamina, 2016).

För att kontrollera reliabiliteten av lyssnarvärderingarna togs en infödd talare av finlandssvenska med i lyssningstestet. Talaren är en 30-årig kvinna från huvudstadsregionen och hennes uttal är nära det finlandssvenska standarduttalet. ${ }^{3}$ Talaren spelade in en liknande monologuppgift som inlärarna. För att lyssningstestet inte skulle bli för långt, togs endast en infödd talare med $i$ testet trots att flera infödda talare skulle ha gett en mer reliabel bild av lyssnarnas förmåga att värdera uttal. Ett större antal talprov med infödda talare kan dock göra värderingarna striktare i lyssningstestet (Flege \& Fletcher, 1992). Värderingarna för den finlandssvenska talaren används också som jämförelsepunkt för att visa hur bra uttal infödda talare producerar i en liknande uppgift och hur deras uttal värderas med samma kriterier. Om någon lyssnare gav mycket låga värderingar för den finlandssvenska talaren, beaktades hans eller hennes värderingar inte. En finskspråkig lyssnare utelämnades från analysen, eftersom hen hade värderat dialektala uttalsdrag och uttalslättnader (t.ex. kortstavighet $\mathrm{i}$ uttalet) som fel hos den finlandssvenska talaren och hos några S2-talare. Detta visade att hen inte kunde identifiera vad som är finlandssvenskt uttal och studenten medgav också själv efter lyssnandet att hen hade stora svårigheter med uppgiften. Därför ansågs studentens svar inte vara tillräckligt tillförlitliga för studien.

\section{Lyssnarna}

Testdeltagarnas prestationer i monologuppgiften värderades auditivt av finsk- och svenskspråkiga halvprofessionella lyssnare $(n=18)$ gällande hur bra talarna behärskar segment och prosodi i

\footnotetext{
${ }^{3}$ Det finns dock olika dialekter inom finlandssvenska och dessa visar relativt mycket variation i uttalet (se t.ex. Ivars 2015).
} 
finlandssvenska. Lyssnarna var universitetsstudenter i svenska från tre olika universitet och de hade fått undervisning i svensk (både finlandssvensk och sverigesvensk) fonetik och uttal. En del hade även gått i lärarutbildning och ska bli lärare i svenska (som andraspråk eller som modersmål). Majoriteten av lyssnarna var i slutfasen av studierna; de flesta hade studerat svenska vid universitet i över 4 år. Den finskspråkiga gruppen ( $n=10$, alla kvinnor) bestod av universitetsstudenter i svenska med finska som S1. Också de svenskspråkiga lyssnarna ( $n=8,6$ kvinnor och 2 män) studerade svenska vid universitet, men de hade (finlands)svenska som S1 eller ansåg sig vara tvåspråkiga i svenska och finska. Eftersom finska är ett dominerande majoritetsspråk i Finland är majoriteten av den svenskspråkiga befolkningen mer eller mindre tvåspråkig i svenska och finska. Lyssnarna var 21-36 år gamla (en lyssnare hade inte angett åldern), och alla angav att de har normal hörsel.

Av de tio finskspråkiga lyssnarna angav fem att de har finlandssvenska som sitt eget uttalsmål, fyra lyssnare hade sverigesvenska som uttalsmål och en varierade uttalet beroende på situationen. De finskspråkiga lyssnarnas kunskaper om finlandssvenskt uttal frågades också efter i bakgrundsformuläret. Alla utom en svarade att de känner till finlandssvenskt uttal bra, mycket bra eller utmärkt (skalan var dåligt - ganska dåligt - bra - mycket bra - utmärkt). Alla svenskspråkiga lyssnare hade finlandssvenskt uttal, och alla utom en talade ibland dialektalt men de kunde också tala standardspråk.

Valet av dessa lyssnargrupper motiveras av att behärskning av fonetiska begrepp och teoretiska insikter $\mathrm{i}$ svenskt uttal krävdes för att säkra att värderingarna kan anses tillförlitliga och att lyssnarna kan beskriva uttalet på ett sakkunnigt sätt (jfr Derwing \& Munro, 2015: 114; Isaacs \& Thomson, 2013). I fritt tal kan det förekomma avvikelser och fel utanför den fonetiska/fonologiska nivån (t.ex. grammatik, ordförrådet och idiomatiskt språkbruk), vilket gör att en viss expertis krävs av lyssnarna så att dessa inte påverkar värderingarna. I bakgrundsformuläret frågades om hur bekanta lyssnarna är med svensk fonetik och värdering av uttal. Lyssnarna angav att deras kunskaper om svensk fonetik var bra eller utmärkta, endast tre av arton lyssnare tyckte att de är ganska dåliga (skalan var mycket dåliga - ganska dåliga - bra mycket bra - utmärkta). Däremot hade majoriteten inte alls eller bara lite erfarenhet av att värdera uttal, och enbart två lyssnare hade ganska mycket erfarenhet av värdering (på skalan inte alls - bara lite - en del-ganska mycket-mycket).

Lyssnarnas vana att höra brytning kan påverka förmågan att upptäcka brytning och värdera den (t.ex. Boyd, 2003; se dock Flege, 1984; Kennedy \& Trofimovich, 2008). I denna studie varierade lyssnarnas vana att höra svenska med finsk brytning så att de hade hört denna brytning åtminstone ibland, i de flesta fall ofta eller mycket ofta (på skalan inte alls - sällan - ibland - ganska ofta - mycket ofta). Förhållandet mellan de olika bakgrundsvariablerna och resultaten redogörs för i analysen.

Att antalet lyssnare inte är större förklaras av uppgiftens natur. I den typ av test som görs här har antalet lyssnare ofta varit relativt litet. Däremot har lyssnarna varit insatta i uttalet och fonetik (professionella eller halvprofessionella lyssnare liksom i denna studie) och analysen har varit relativt detaljerad (jfr Derwing m.fl., 2004; Meister \& Meister, 2007; Trofimovich \& Isaacs, 2012). När lyssnarna har expertis inom området kan reliabla resultat nås även med ett litet antal lyssnare.

\section{Genomförandet av lyssningstestet}


I lyssningstestet används en värderingsmatris som skapats för värdering av svenskt uttal (Heinonen \& Kautonen, 2017). Matrisen kan användas för att värdera olika uttalsdrag både i uppläst och fritt tal. Tillämpningen av denna design i föreliggande studie presenteras i tabell 2.

Tabell 2. Värderingsmatrisen i lyssningstestet.

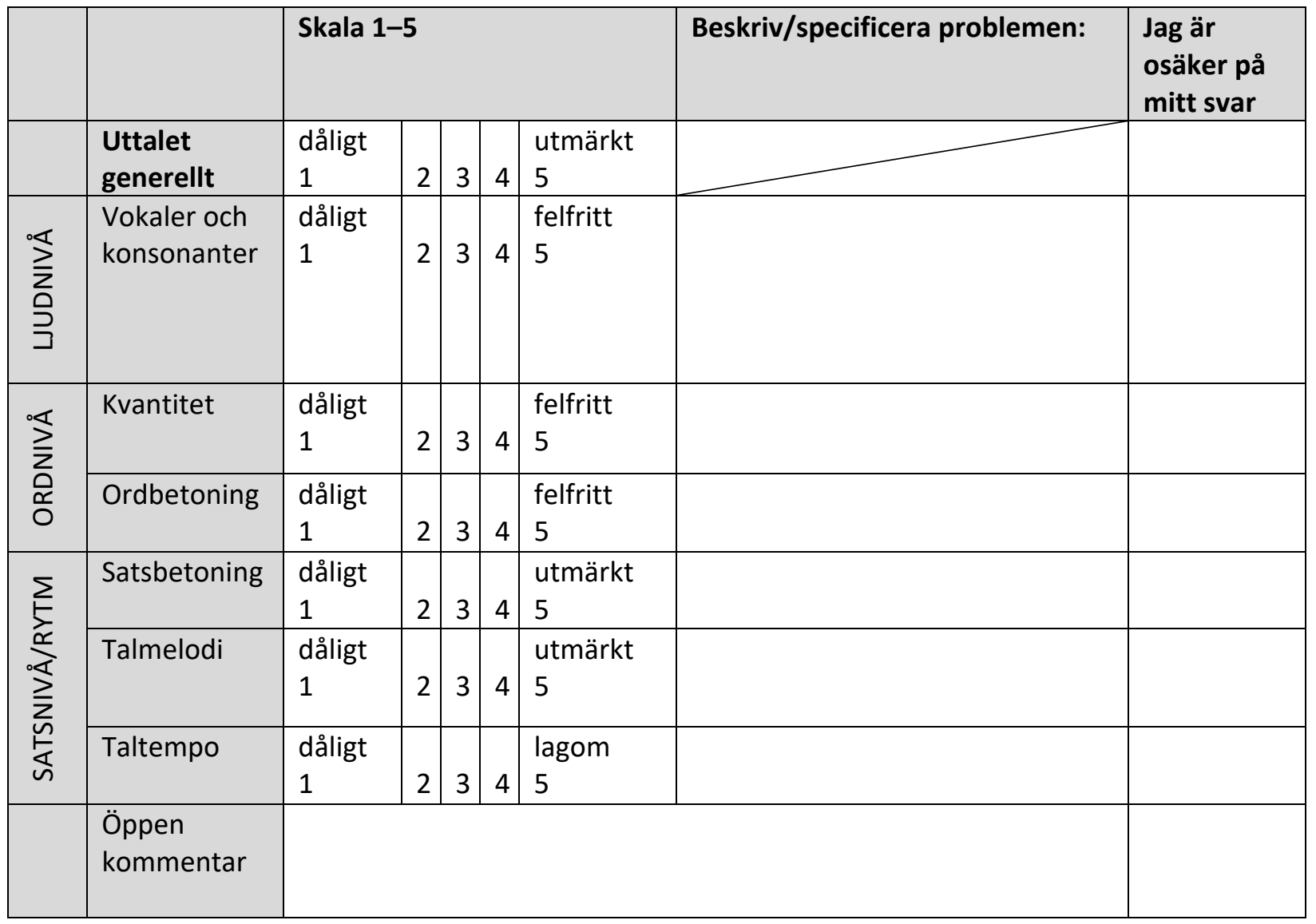

I lyssningstestet värderade lyssnarna talproven på skalan 1-5 (1=dåligt, 2=ganska dåligt, 3=bra, 4=mycket bra, 5=utmärkt/felfritt) gällande uttalet i allmänhet samt enstaka uttalsdrag på ljud-, ord- och satsnivå. Under lyssnandet hade lyssnarna den verbaliserade skalan i början av värderingsmatrisen, medan i de tabeller där de markerade sina svar fanns enbart benämningar på extremvärdena. De uttalsdrag som värderades var vokaler och konsonanter, kvantitet, ordbetoning, satsbetoning, talmelodi och taltempo (jfr delvis liknande kategorier i Saito m.fl., 2017; Trofimovich \& Isaacs, 2012). De tre kategorierna på satsnivån - satsbetoning, talmelodi och taltempo - anses utforma rytm och därför ingick inte rytm som separat kategori i matrisen. Lyssnarna fick dock nämna andra kategorier som de ansåg viktiga. Därtill ombads lyssnarna specificera de svårigheter som talarna hade med en viss kategori. Lyssnarna kunde också kryssa i värderingsmatrisen om de var osäkra på sina svar gällande någon kategori. En skala på 1-5 är lättare att använda och beskriva för lyssnaren än skalor med ännu fler steg (Isaacs \& Thomson, 2013) även om också sådana har använts (se Jesney, 2004). Ett pilottest genomfördes med tre professionella lyssnare och några finslipningar gjordes $\mathrm{i}$ testet. Dessutom kommenterade en rad värderingsexperter värderingsmatrisen och testdesignen. 
Lyssningstestet genomfördes som kursuppgift för studenterna. Därtill fick frivilliga studenter delta i testet utanför lektionerna. Lyssningstestet genomfördes med samma procedur i alla lyssnargrupper. Lyssnarna fick se instruktionerna och värderingsblanketten ca en vecka före testet; vad de ska värdera och hur de ska göra det. Testet börjades med en genomgång av instruktionerna, varefter jag svarade på eventuella frågor hos lyssnarna. De fick också lyssna på ett exempelprov och se hur blanketten ska fyllas i.

Lyssningstestet arrangerades så att alla lyssnare kunde höra talproven med hörlurar och med dator. De lyssnade på talproven i olika ordning och fick själva klicka sig vidare till nästa talprov. Lyssnarna ombads att lyssna på talproven 2-3 gånger, men inte använda för mycket tid för värderingen av varje enskilt talprov så att testet inte skulle ta mer än ca 60 minuter. Detta är ett maximum som rekommenderas för lyssnandet så att resultaten inte påverkas av att lyssnarna blir trötta och tappar koncentrationen (jfr Saito m.fl., 2017). Att kunna lyssna på ett talprov flera gånger var nödvändigt för att lyssnarvärderingarna blev reliabla och detaljerade (Derwing \& Munro, 2015: 117; se dock Saito m.fl., 2017 om hur lyssnarna sällan valde att lyssna på talproven på nytt). Lyssnarna fick också pausa talproven när de ville.

Lyssnarna fick ingen modell av finlandssvenskt måluttal, utan de ombads använda den kunskap om finlandssvenska som de hade fått genom utbildning och egna erfarenheter. Som modell för finlandssvenskt uttal används vid flera universitet beskrivningar av finlandssvenskt uttal t.ex. i Kuronen och Leinonen (2010) samt Reuter (2015). I skolundervisningen är den valda uttalsmodellen av (finlands)svenska ofta standardfinlandssvenska och därför var det sannolikt att lyssnarna skulle använda just standardfinlandssvenska som jämförelsepunkt i sina värderingar.

\section{Analys}

Några enstaka skalvärderingar saknades i lyssnarsvaren. Dessa lämnades tomma i analysen och de påverkade således inte genomsnitten. Lyssnarna informerades i början av testet att om de ansåg att uttalet är helt felfritt, kan de enbart ge helhetsvärderingen 5 för uttalet vilket betyder att också de olika delkategorierna är värda en 5 . Lyssnarna kunde dock ge separata värderingar för de individuella kategorierna trots helhetsvärderingen 5 . De talprov som värderats enbart med en 5 för uttalet, tilldelade jag 5 också i de andra kategorierna så att de tomma svaren inte skulle förvränga resultaten i analysfasen.

Genomsnitt av lyssnarnas svar räknades med Excel och de statistiska analyserna gjordes med dataprogrammet SPSS 24.0. Korrelationer räknades med Spearmans rangkorrelation, signifikans av skillnaderna med Mann-Whitney U-test, Wilcoxon signed rank test och Kruskal Wallis-test, och reliabiliteten mellan lyssnarna med Intraclass Correlation Coefficient (ICC) och Cronbachs alfa (Pallant, 2005; Nummenmaa, 2009). Signifikansnivån i beräkningarna är $p<0,05$. Därtill jämfördes talarna, lyssnarna och lyssnarvärderingarna med programmet Facets (Linacre, 2017).

\section{Resultat}

I följande tre avsnitt presenteras hurdana svårigheter talarna hade med S2-uttalet av finlandssvenska, skillnader mellan de olika färdighetsnivåerna och mellan de två lyssnargruppernas värderingar.

\subsection{Uttalsavvikelser hos S2-talarna}


Resultaten visar att det förekommer målspråksavvikelser i uttalet även på de högsta färdighetsnivåerna (figur 1). Även om talarna har mycket bra uttal, når de genomsnittligt inte upptill felfritt uttal (5) utmed någon av kategorierna. De största svårigheterna förekommer i enstaka ljud, satsbetoning, talmelodi och taltempo, medan ordbetoning och kvantitet uppfattas oftast som utmärkta.

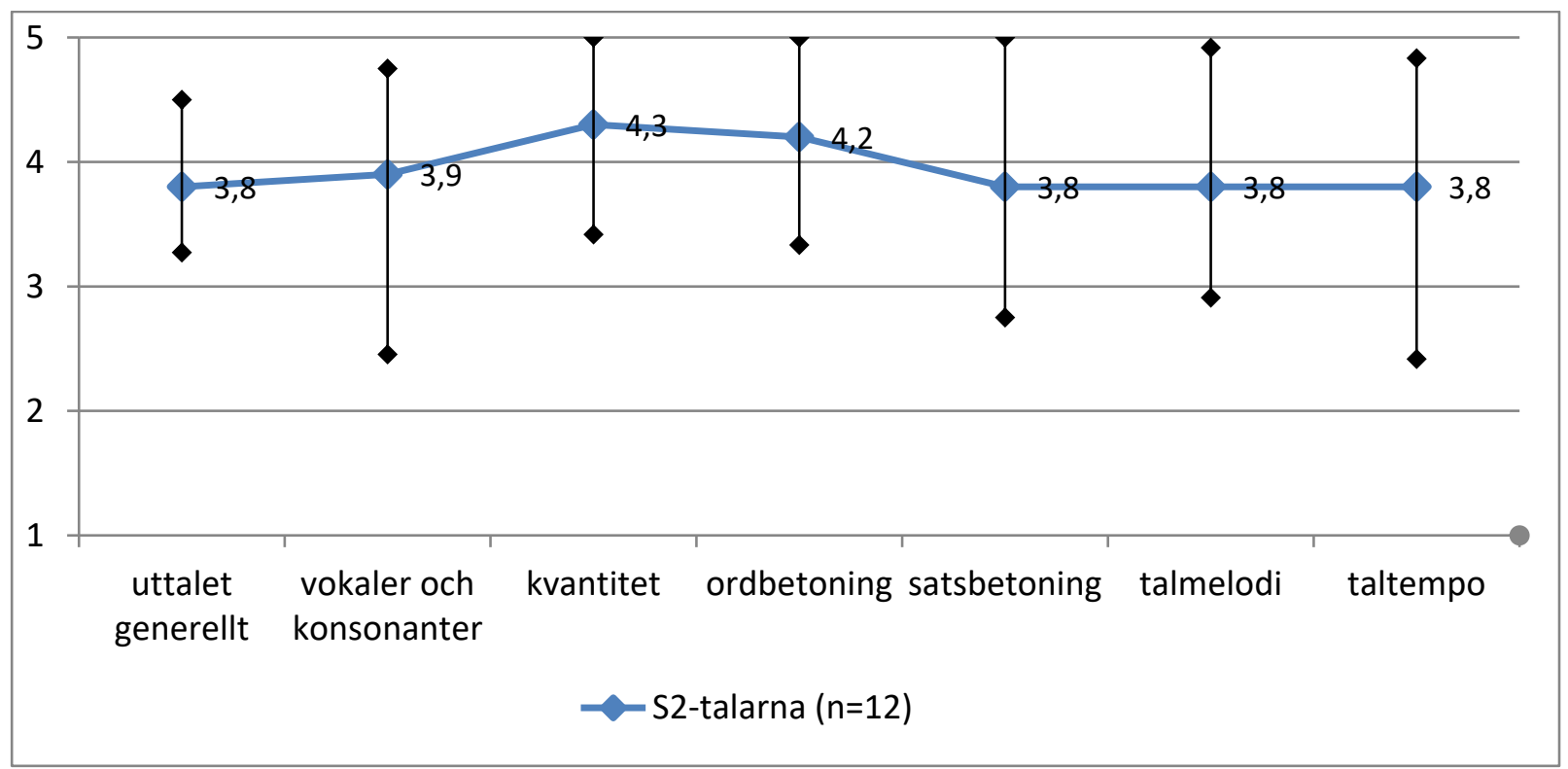

Figur 1. S2-talarnas ( $\mathrm{n}=12$ ) färdigheter i de olika uttalskategorierna på skalan 1-5 (1=dåligt, 2=ganska dåligt, 3=bra, 4=mycket bra, 5=utmärkt/felfritt) enligt lyssnarvärderingarna ( $n=18)$. I figuren visas också spridningen av de genomsnittliga lyssnarvärderingarna (=vertikala streck).

De typiska svårigheterna hos talarna sammanfattas i tabell 3. Vad gäller segment angav lyssnarna att det fanns avvikelser $\mathrm{i} / \mathrm{t} /, / \mathrm{J} / \mathrm{,} / \mathrm{t} /$ / som saknas i finska, avtoning eller för svag stämton $\mathrm{i} / \mathrm{b} /$ och / g/ och svårigheter med att åtskilja /e/ och /æ/, /u/ och /o/ samt /u/, / / och /y/ i vissa ord. Talarna hade också svårigheter med [f] som uttalades ibland som [v], de använde halvslutet [ $\varnothing$ ] i stället för halvöppet [œ] och hade för kraftiga [g] och [r]. En mycket vanlig avvikelse även bland de duktigaste talarna förekom $\mathrm{i}$ presensändelsen -er som ofta uttalades som [er] i stället för [ær]. Därtill kommenterade lyssnarna enstaka tillägg och bortfall av fonem. Svårigheterna på ljudnivån förekom både i korta och långa ljud och i betonade och obetonade positioner, t.ex. med [ $\mathrm{t}$ :] resp. $[\mathrm{H}]$ i njut, beslut, kunde (felaktig vokalkvalitet), [æ] i tänker (uttal med [er]) och [g] i gruppen, negativa (uttal med [k]). På ljudnivån är det ofta fråga om små men ändå hörbara avvikelser som upplevs som brytning (jfr variationen hos infödda talare $\mathrm{i}$ Kuronen, 2016b och Ringen \& Suomi, 2012).

På ordnivån nämnde lyssnarna enstaka ord och stavelser som uttalades med felaktig längd. Både för korta och för långa ljud nämndes förekomma i materialet, t.ex. ordet alkohol uttalades som ['alkohol] i stället för [alko'ho:I] och många som ['mon:a:] i stället för ['mon:a]. Ordbetoning nämndes ibland vara på fel stavelse i ord som sommaren, ensamma, helhet och bråttom eller ordbetoningen saknades. Att ordnivån medför minst problem följer resultaten hos talare på de lägre färdighetsnivåerna (Kautonen, 2016). 
I de specificerade lyssnarkommentarerna på satsnivån nämnde lyssnarna ofta att satsbetoningen används för ofta och att för många ord betonas. I enbart några lyssnarkommentarer nämndes att satsbetoning saknas. Talmelodin kommenterades för det mesta vara för monoton och sakna toppar och fall. I vissa fall kommenterade lyssnarna att intonationen varierar för mycket eller att meloditopparna ligger på avvikande ställen. Taltempot bedömdes av lyssnarna som för långsamt hos S2-talarna, och endast den finlandssvenska talaren och några S2-talare kommenterades ibland tala lite för snabbt. Flera lyssnare nämnde hackigheten och pauser i samband med tempot och tyckte att pauser påverkade störande upplevd rytm och intrycket av satsbetoning och talmelodi.

Tabell 3. Typiska svårigheter i S2-uttalet hos avancerade finskspråkiga talare av finlandssvenska.

\begin{tabular}{|c|c|c|c|c|c|}
\hline & \multicolumn{5}{|c|}{ Typiska svårigheter } \\
\hline $\begin{array}{l}\text { Vokaler och } \\
\text { konsonanter }\end{array}$ & $\begin{array}{l}\text { felaktig kvalitet i } \\
{[\mathrm{H}],[\mathrm{t}:]} \\
{[],[\mathrm{t}]}\end{array}$ & $\begin{array}{l}\text { stämton i [b], } \\
\text { [g] }\end{array}$ & $\begin{array}{l}\text { sammanblandning } \\
\text { av }[\mathrm{e}] \text { och[æ], } \\
{[\mathrm{u}] \text { och }[\mathrm{o}],} \\
\text { samt }[\mathrm{u}],[\mathrm{H}] \text { och }[\mathrm{y}]\end{array}$ & $\begin{array}{l}\text { felaktig } \\
\text { ersättning: } \\
{[f]>[v]} \\
{[œ]>[\varnothing]}\end{array}$ & $\begin{array}{l}\text { för kraftiga } \\
\text { [g] och [r] }\end{array}$ \\
\hline Kvantitet & \multicolumn{5}{|c|}{ felaktiga vokal- och konsonantlängder } \\
\hline Ordbetoning & \multicolumn{2}{|c|}{ ordbetoning saknas } & \multicolumn{3}{|c|}{ felaktig placering av ordbetoning } \\
\hline Satsbetoning & $\begin{array}{l}\text { satsbetoning } \\
\text { saknas }\end{array}$ & \multicolumn{2}{|c|}{ onaturlig placering av satsbetoning } & \multicolumn{2}{|c|}{ för många ord betonas } \\
\hline Talmelodi & för monoton & $\begin{array}{l}\text { saknar melodi- } \\
\text { toppar och fall }\end{array}$ & $\begin{array}{l}\text { intonationen } \\
\text { varierar för mycket }\end{array}$ & \multicolumn{2}{|c|}{$\begin{array}{l}\text { onaturlig placering av } \\
\text { meloditoppar }\end{array}$} \\
\hline Taltempo & \multicolumn{2}{|l|}{ för långsamt } & \multicolumn{3}{|l|}{ för snabbt } \\
\hline Annat & \multicolumn{5}{|c|}{ onaturlig pausering } \\
\hline
\end{tabular}

Uttalssvårigheterna hos avancerade talare gäller relativt fina - nästan allofoniska - avvikelser i segment medan variationen på satsnivån är mer markant. I följande avsnitt presenteras hur svårigheterna är fördelade på de olika färdighetsnivåerna av muntlig färdighet.

\subsection{Uttalet på olika färdighetsnivåer}

I figur 2 anges hur uttalet skiljer sig åt på de olika färdighetsnivåerna. Det finns inga stora skillnader mellan nivåerna B2 och C1, och nivån C2 ligger mycket nära inföddlikt uttal. Även den finlandssvenska talaren fick några få kommentarer om onaturlig satsbetoning och för snabbt taltempo. Ändå identifierades talaren som S1-talare. Detta tyder på att vissa avvikelser sannolikt tolererats även hos de duktigaste S2-talarna. Skillnaderna mellan nivåerna B2 och C2 samt mellan C1 och C2 är statistiskt signifikanta för alla värderingar (Mann-Whitney U-test $p<0,0005$ ). Färdighetsnivån korrelerar också positivt med färdigheter $i$ de individuella kategorierna $(r=0,578-0,770, p=0,003-0,049)$. Mann-Whitney U-testet visar statistiskt signifikanta skillnader mellan nivåerna B2 och C2 i alla kategorier förutom taltempo och mellan nivåerna C1 och C2 i segment, kvantitet och satsbetoning ( $p=0,020-0,042$ ). Skillnaderna i kvantitet och satsbetoning är statistiskt signifikanta mellan nivåerna B2 och C2 också enligt Kruskal Wallis-testet ( $p=0,032$ för kvantitet resp. $p=0,048$ för satsbetoning). 


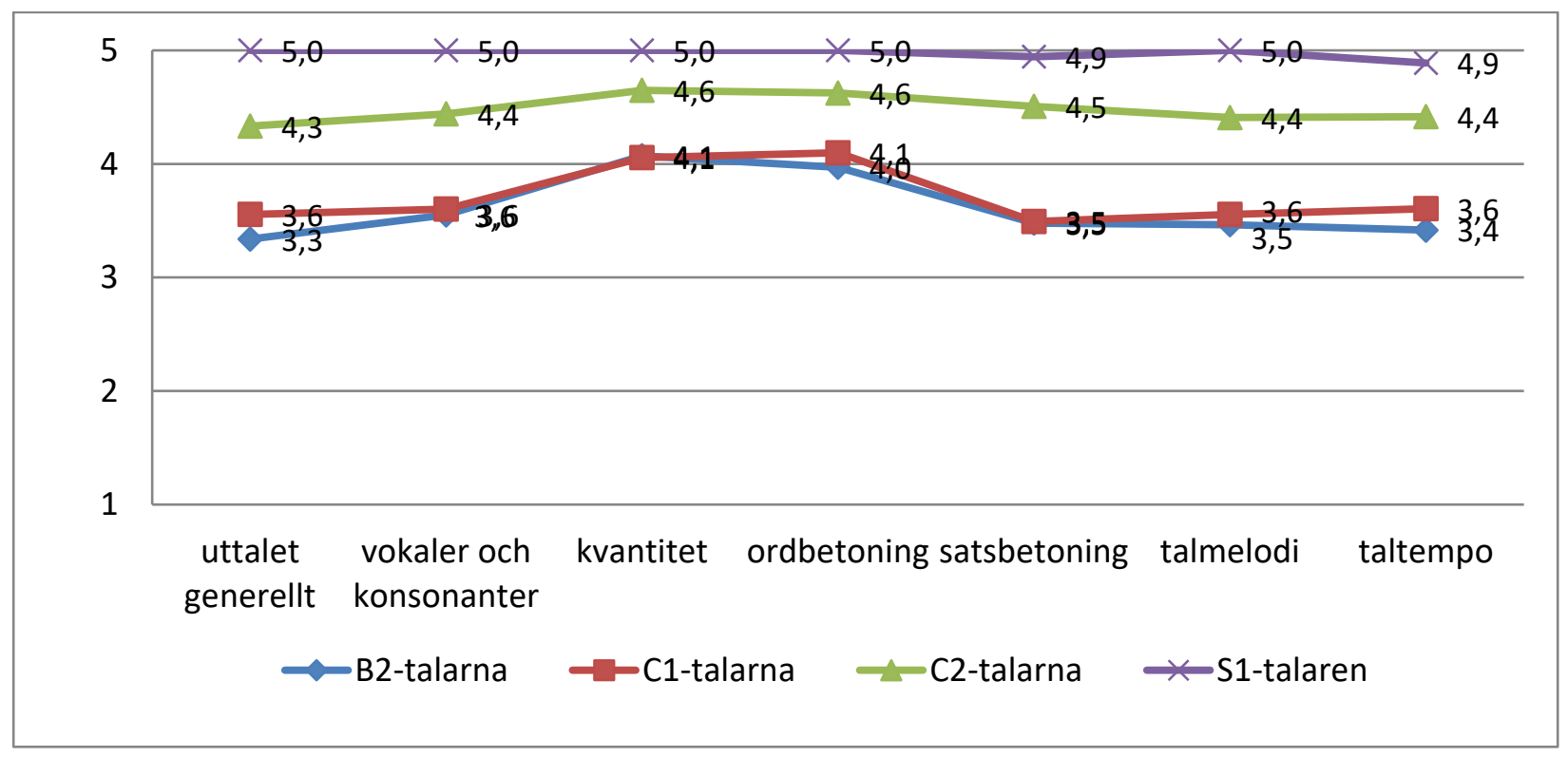

Figur 2. Lyssnarnas värdering av uttalet på skalan 1-5 (1=dåligt, 2=ganska dåligt, 3=bra, 4=mycket bra, $5=u t m a ̈ r k t / f e l f r i t t)$ på färdighetsnivåerna B2, C1 och C2 samt hos den finlandssvenska S1-talaren.

Alla kategorier har markant högre värderingar på nivån C2 än på nivåerna B2 och C1. Talarna behärskar kvantitet och ordbetoning bäst på alla nivåer. På nivåerna B2 och C1 är värderingarna för segment och satsprosodiska drag i linje med helhetsvärderingen; alla dessa behärskas bra eller mycket bra. På nivån C2 förekommer enbart enstaka avvikelser i uttalet, för det mesta i segment, talmelodi och taltempo. Talarnas uttalsfärdigheter hänger relativt bra ihop med nivåtilldelningen enligt Facets-analysen: bland de fyra svagaste talarna finns två talare från nivån B2 och två talare från nivån C1, medan bland de fyra duktigaste S2-talarna finns tre C2-talare och en C1-talare.

I lyssnarkommentarerna förekom inga stora skillnader på de olika färdighetsnivåerna. Särskilt på nivåerna B2 och C1 kommenterade lyssnarna att talarna betonar för mycket och har satsbetoningen på onaturliga ställen. Fast uttalet ansågs vara utmärkt (5) enligt flera lyssnare, kunde talarna ha enstaka svårigheter/feluttal i olika kategorier även på de högsta färdighetsnivåerna. I huvudsak var det då fråga om en avvikande satsbetoning, talmelodi eller enstaka feluttalade segment, speciellt sammanblandning av [e] och [æ] samt feluttal av [ $\forall$ ] och [ $\sharp$ :]. Taltempot kunde också vara för snabbt hos dessa talare.

Jämförelser av de genomsnittliga värdena hos en och samma talare visar att skillnaden mellan helhetsvärderingen, dvs. kategorin uttalet generellt, och de individuella dragen är minst för satsbetoning. Korrelationerna var också störst mellan helhetsvärdering och satsbetoning för alla lyssnarvärderingar $(r=0,956, p<0,0005)$. Hos de svenskspråkiga lyssnarna var korrelationen störst för satsbetoning $(r=0,950$, $p<0,0005)$, medan både talmelodi och satsbetoning hade starkast korrelation med helhetsvärderingen hos de finskspråkiga lyssnarna ( $r=0,957$ för talmelodi och $r=0,956$ för satsbetoning, $p<0,0005$ ). Sammantaget kan detta tolkas som att det är de prosodiska dragen, i synnerhet satsbetoning, som tycks påverka helhetsvärderingen mest.

\subsection{De olika lyssnargrupperna}


Genomsnitten av lyssnarvärderingarna hos de två lyssnargrupperna visas i figur 3. De svenskspråkiga lyssnarna värderade alla kategorier striktare, särskilt ordbetoning, kvantitet, satsbetoning och segment även om skillnaderna i helhetsvärderingarna är små. Skillnaderna mellan lyssnargrupperna är statistiskt signifikanta (Wilcoxon signed rank test $p=0,002-0,023$ för de olika kategorierna). Skillnaden var störst och mest signifikant för ordbetoning och kvantitet ( $p=0,002$ för ordbetoning, $p=0,003$ för kvantitet). Lyssnarna var dock relativt eniga i sina värderingar (Cronbachs alfa 0,933 och ICC 0,362 för alla lyssnare; 0,889 och 0,385 för finskspråkiga och 0,880 och 0,423 för svenskspråkiga lyssnare). Enigheten bland lyssnarna var störst för uttalet generellt, segment och taltempo och minst för kvantitet och ordbetoning. Båda grupper identifierade den svenskspråkiga talaren med stor säkerhet och gav värderingen 5 för uttalet. Det fanns dock skillnader mellan lyssnargrupperna i vilka S2-talare som tilldelades värderingen 5. I de finskspråkiga lyssnarnas svar hade sju S2-talare fått åtminstone en (1) värdering av 5 för uttalet (en talare på nivån B2, två på nivån C1 och fyra på nivån C2), medan i de svenskspråkiga lyssnarsvaren fanns det fem S2-talare som tilldelats värderingen 5 (en talare på nivån C1 och fyra på nivån C2).

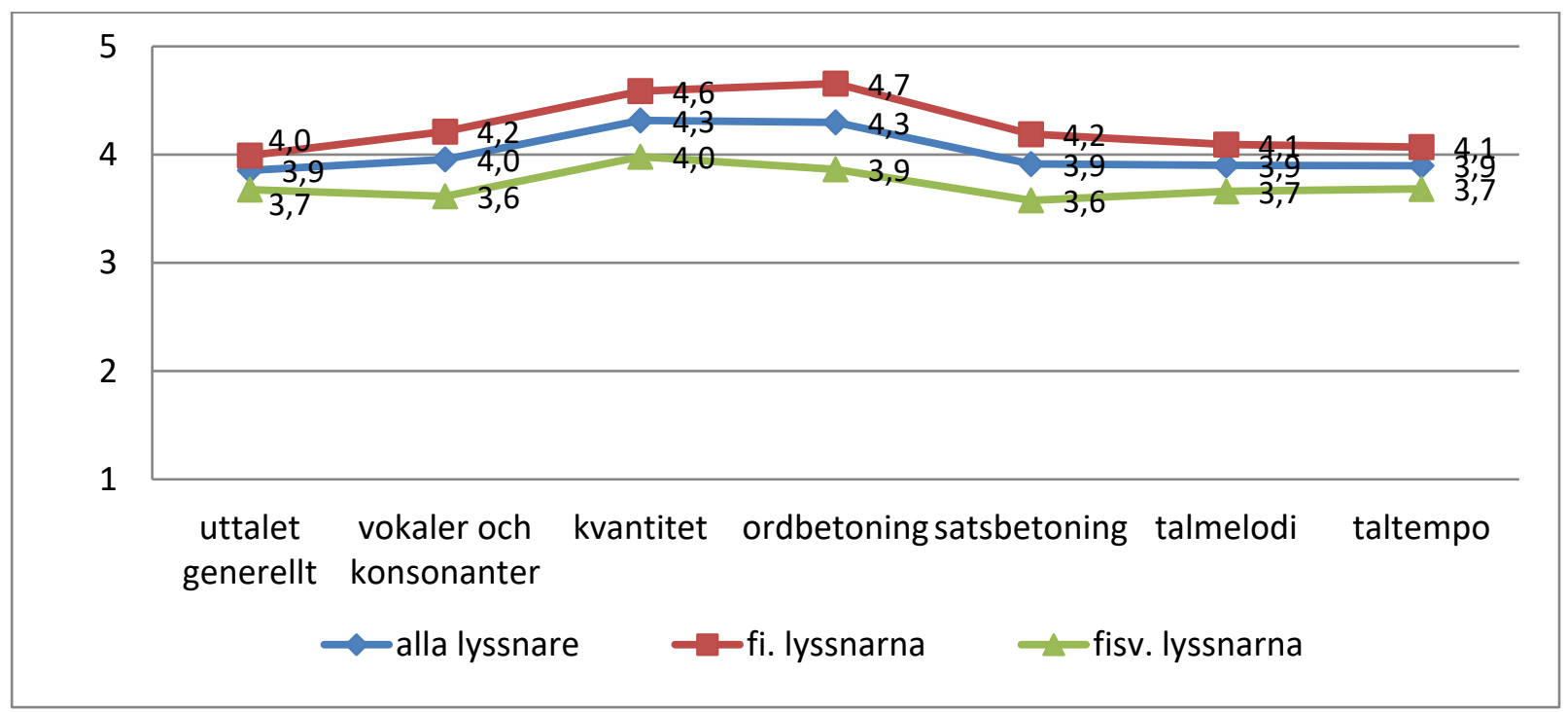

Figur 3. Genomsnitt av de olika lyssnargruppernas (fi.=finskspråkiga lyssnare, fisv.=svenskspråkiga lyssnare) värderingar för alla talare (S2-talarna och S1-talaren).

De två lyssnargruppernas värderingar för talarna på de olika färdighetsnivåerna jämförs i figur 4. Figuren visar att de svenskspråkiga lyssnarna var duktigare på att skilja grupperna åt. Skillnaderna mellan lyssnargrupperna är störst på nivån B2 och minskar när nivån är högre. På nivån C1 är värdena nära varandra förutom för segment och ordbetoning där de svenskspråkiga lyssnarna har gett markant lägre värderingar. De finskspråkiga lyssnarnas värderingar för alla kategorier ligger närmare varandra på de olika nivåerna än hos de svenskspråkiga lyssnarna, vars värderingar visar en tydligare skillnad mellan uttalet på de olika färdighetsnivåerna. I båda lyssnargrupper finns signifikanta skillnader mellan nivåerna B2 och C2 samt mellan C1 och C2 för alla värderingar (Mann-Whitney U-test $p<0,0005$ ). Vidare finns det statistiskt signifikanta skillnader i de svenskspråkiga lyssnarnas svar mellan nivåerna B2 och C2 i alla kategorier förutom taltempo ( $p=0,020-0,043)$ och mellan nivåerna C1 och C2 i uttal, segment, kvantitet, satsbetoning och talmelodi $(p=0,020-0,043)$. I de finskspråkiga lyssnarnas svar finns statistiskt signifikanta skillnader enbart mellan nivåerna C1 och C2 i segment och satsbetoning (Mann-Whitney Utest $p=0,026-0,043$ ). Därtill visar Kruskal Wallis-testet att skillnaderna i uttal, kvantitet och satsbetoning 
var statistiskt signifikanta i de svenskspråkiga lyssnarnas svar mellan nivåerna B2 och C2 ( $p=0,018$ för uttal, $p=0,024$ för kvantitet resp. $p=0,032$ för satsbetoning).

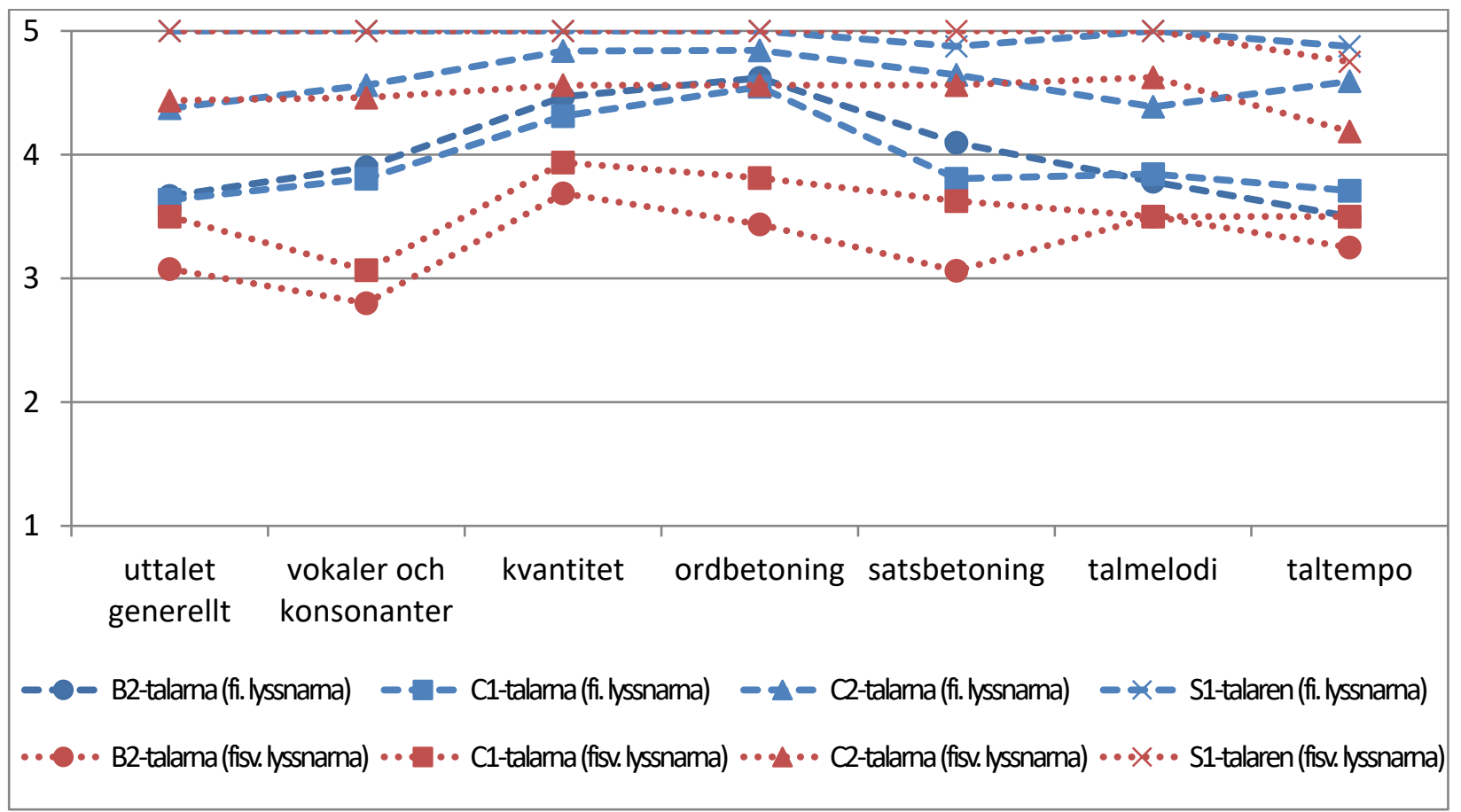

Figur 4. Genomsnitten av de olika lyssnargruppernas värderingar för talare på de olika färdighetsnivåerna ( $n=12$ ) enligt de finskspråkiga lyssnarna (fi., $n=10$, markeras med blått) och de svenskspråkiga lyssnarna (fisv., $n=8$, markeras med rött).

De svenskspråkiga lyssnarna specificerade svårigheter oftare än de finskspråkiga lyssnarna (385 resp. 179 specificeringar). Specificeringarna var relativt lika till innehåll mellan grupperna, men det förekom skillnader mellan olika lyssnare. Lyssnarna lade märke till olika drag särskilt när det gäller segment. Hos båda grupper fanns det också några relativt oklara specificeringar som visar att lyssnarna ibland har haft svårigheter att beskriva uttalet i de olika kategorierna, t.ex. ingen intonation, och exempel på ordbetoning beskrev ibland satsbetoning eller tvärtom.

De svenskspråkiga lyssnarna var relativt säkra på sina värderingar (tabell 4). De hade sammanlagt 15 markeringar för osäkert svar (1,9 markeringar/lyssnare), medan de finskspråkiga lyssnarna hade 39 markeringar (3,9 markeringar/lyssnare). Denna osäkerhet tycks synas också i värderingarna på så sätt att det finns färre statistiskt signifikanta skillnader mellan de olika färdighetsnivåerna i de finskspråkiga lyssnarnas svar. Enbart två finskspråkiga lyssnare angav aldrig att de var osäkra på sina svar, medan det fanns sex sådana lyssnare bland de svenskspråkiga. I de finskspråkiga lyssnarnas svar nämndes alla kategorier, varav ordbetoning och satsbetoning var svårast. Ordbetoning var den svåraste kategorin att värdera också enligt de svenskspråkiga lyssnarna, men vokaler och konsonanter och taltempo nämnde de däremot aldrig.

Tabell 4. Osäkra svar för olika kategorier i lyssnarvärderingar $(n=18)$. 


\begin{tabular}{|c|c|c|c|c|c|c|c|}
\hline & $\begin{array}{c}\text { Uttalet i } \\
\text { allmänhet }\end{array}$ & $\begin{array}{c}\text { Vokaler och } \\
\text { konsonanter }\end{array}$ & Kvantitet & $\begin{array}{c}\text { Ord- } \\
\text { betoning }\end{array}$ & $\begin{array}{c}\text { Sats- } \\
\text { betoning }\end{array}$ & Talmelodi & Taltempo \\
\hline $\begin{array}{c}\text { Finskspråkiga } \\
\text { lyssnare ( } \mathrm{n}=10)\end{array}$ & 6 & 4 & 5 & 10 & 8 & 3 & 3 \\
$\begin{array}{c}\text { Svenskspråkiga } \\
\text { lyssnare ( } \mathrm{n}=8)\end{array}$ & 3 & 0 & 3 & 5 & 2 & 2 & 0 \\
Sammanlagt & 9 & 4 & 8 & 15 & 10 & 5 & 3 \\
\hline
\end{tabular}

För att utreda om skillnaderna mellan lyssnarna beror på några andra bakgrundsvariabler än deras S1, testades skillnaderna med programmen Facets och SPSS. De fem lyssnare som genomsnittligt gav de lägsta värderingarna var svenskspråkiga, medan de tre lyssnare som gav de högsta värderingarna var finskspråkiga. Hur strikta lyssnarna var korrelerade medelstarkt med deras vana att höra svenska med finsk brytning: ju oftare de hade hört svenska med finsk brytning, desto striktare var deras värderingar (korrelation $r=-0,568, p=0,014$; Kruskal-Wallis test $p=0,035$ ). Korrelationen var också stark för strikthet och lyssnarens S1 ( $r=-0,668, p=0,002$; Mann-Whitney U-test $p=0,006)$. Det framkom inga statistiskt signifikanta skillnader mellan lyssnarna beroende på vilken varietet av svenska de själva talar, kunskaper i fonetik, erfarenheter i uttalsvärdering och hos finskspråkiga lyssnare beroende på hur bra de känner till finlandssvenskt uttal.

\section{Diskussion}

Syftet med studien var att analysera avancerade finskspråkiga språkinlärares uttal av finlandssvenska och hurdana uttalssvårigheter talarna har på olika färdighetsnivåer. En ytterligare forskningsfråga var om finskspråkiga och svenskspråkiga lyssnare värderar uttalet på samma sätt. Sammanfattningsvis visar resultaten att:

(i) Det förekommer målspråksavvikelser både i segment och i prosodi. Talarna behärskar kvantitet och ordbetoning bäst, medan vokaler, konsonanter och satsprosodiska drag förorsakar mest svårigheter.

(ii) På nivåerna B2 och C1 har talarna signifikant flera svårigheter med segment och satsprosodiska drag än på den högsta nivån C2 där det förekommer enbart några mindre, närmast allofoniska avvikelser $\mathrm{i}$ segment och avvikande satsbetoning och melodi.

(iii) De svenskspråkiga lyssnarna värderar uttalet striktare än de finskspråkiga lyssnarna och de är säkrare på sina värderingar. Helhetsvärderingarna för uttalet är relativt lika mellan lyssnargrupperna, medan särskilt ordbetoning och kvantitet värderas mycket striktare av den svenskspråkiga gruppen.

Resultaten visar att uttalet inte alltid är helt målspråkslikt ens på de högsta färdighetsnivåerna. Avancerade finskspråkiga talares uttal av finlandssvenska tycks vara holistiskt något målspråksavvikande utan att ett visst drag sticker ut. Satsbetoning tycks dock vara av störst betydelse för lyssnarnas helhetsvärdering av uttalet (jfr Kuronen \& Tergujeff, 2017). Eftersom talarna har svårigheter med fler uttalskategorier än S2-inlärningsteorier förutser (se kapitel 2), är det sannolikt att S2-uttalet påverkas relativt mycket av andra faktorer än enbart inlärarens S1, t.ex. allmänna svårigheter med S2-produktion och också andra språk än S1 kan påverka uttalet (jfr Shriberg, 2001; Wrembel, 2010). Några tydliga inlärningsstigar upptäcktes inte i studien, men uttalet var bättre i alla kategorier när färdighetsnivån var högre. 
Vidare visar resultaten att ett närmast inföddlikt uttal av finlandssvenska är ett möjligt inlärningsmål för åtminstone några finskspråkiga talare. Fem talare fick värdering utmärkt eller inföddliknande uttal i de svenskspråkiga lyssnarnas svar och sju talare i de finskspråkiga lyssnarnas svar. Trots det värderades avancerade talares uttal genomsnittligt vara sämre i alla de undersökta kategorierna än hos den infödda finlandssvenska talaren, och enstaka avvikelser förekom på ljud-, ord- och satsnivån. Samtidigt ansåg några lyssnare att även den infödda talarens prosodi var avvikande eller störande i fråga om taltempo och satsbetoning. Också tidigare studier har visat att några mycket avancerade S2-talare kan värderas vara lika bra som infödda talare (jfr t.ex. Angelovska, 2012).

Studien lyfter fram en viktig fråga om hur felfritt och inföddlikt uttalet ska vara för att det ska betinga de högsta värderingarna i språktesterna och vad som ska vara målet vid uttalsinlärningen. I bedömningskriterierna för de allmänna språkexamina i Finland nämns att uttalet ska vara närmast inföddlikt på nivåerna C1 och C2, medan avvikelser i uttalet kan förekomma på nivån B2 (Allmänna språkexamina, 2016). I denna studie återfanns inga stora skillnader i uttalet mellan nivåerna B2 och C1, vilket åtminstone delvis kan bero på att talarna på nivån B2 har deltagit i mellannivåtestet där det högsta möjliga betyget är B2 och deras språkkunskaper kan i verkligheten vara bättre. De svenskspråkiga lyssnarna upptäckte ändå skillnader mellan talarna på nivåerna B2 och C1 vilket tyder på att talarnas språkfärdigheter faktiskt motsvarar de tilldelade nivåerna. Nivåbedömningen tycks således ha fungerat relativt bra med tanke på uttalskriterierna. Olika slags målspråksavvikelser förekom dock också på de högsta färdighetsnivåerna och det fanns inga drag som alltid behärskades perfekt. Därför är det sannolikt att behärskning av vissa uttalsdrag inte direkt kan kopplas till olika färdighetsnivåer av muntlig färdighet. Sannolikt påverkas intrycket av uttalet snarare av antalet uttalsfel (jfr Toivola, 2011; CunninghamAndersson \& Engstrand, 1989) och att de mest bestående uttalsfelen inte värderas vara lika kritiska som andra. Ett helt felfritt uttal utan några målspråksavvikelser känns därför vara ett omotiverat och orealistiskt mål i språktesterna - också med tanke på att det kan finnas felsägningar även i infödda talares uttal.

I sina svar tog lyssnarna upp dialektala drag i talproven och den höga nivån av språkfärdigheter hos talarna. Det var oklart för några lyssnare hur de ska bedöma dialekter: ska det finnas några instruktioner för testdeltagare och bedömare i språktester om dialektalt språkbruk eller är alla dialekter likvärdiga? Hur är det med talfel, t.ex. [r]-uttal? Några lyssnare angav att de ibland kommenterade petitesser eftersom talarna var så duktiga. Det är därför viktigt att påpeka hur instruktionerna i lyssningstestet kan styra lyssnandet. I vanliga talsituationer skulle lyssnarna kanske inte ha fäst så mycket uppmärksamhet vid några uttalsavvikelser. Dessa frågor måste beaktas framöver vid planering av språktester för att försäkra att värderingarna är enhetliga och ändamålsenliga så att tyngdpunkten är på sådana avvikelser som har betydelse för kommunikationen.

Lyssnarvärderingarna bör i framtiden kompletteras med närmare, också akustiska studier av S2-uttal. Det är viktigt att jämföra lyssnarvärderingarna med talarnas faktiska målspråksavvikelser för att se om de valda lyssnargrupperna kan värdera uttalet på ett tillförlitligt sätt. Intressant är också varför de svenskspråkiga lyssnarna var markant striktare än de finskspråkiga lyssnarna (jfr tidigare studier i kapitel 1). Man kan spekulera om det t.ex. beror på minoritetsrollen som finlandssvenska har i Finland och olika försök att bli av med svenska som ett obligatoriskt ämne i skolan, eller om finskspråkiga lyssnare inte känner till finlandssvenskt uttal tillräckligt bra och inte upptäcker alla målspråksavvikelser i uttalet. Ett 
ytterligare förslag till fortsatt forskning är att undersöka närmare hurdana attityder dessa lyssnargrupper har till variationen i svenskt uttal och om attityderna har någon inverkan på lyssnarvärderingarna.

Studien ingår i projektet FOKUS (www.jyu.fi/fokus) som finansieras av Svenska litteratursällskapet $i$ Finland 2015-2019. Ett stort tack också till alla lyssnare och till Allmänna språkexamina för talmaterialet, och till forskarna i SOLKI för hjälp med Facets-analyser. Jag ber också att få tacka Martina Huhtamäki och Elisabeth Zetterholm för värdefulla kommentarer till artikelmanuset.

\section{Litteratur}

Allmänna språkexamina. (2016). Bedömningskriterierna för muntlig framställning. https://www.jyu.fi/hytk/fi/laitokset/solki/yki/yleista/tietoakielitutkinnoista/puhumisen arviointi kriteerit.pdf [Tillgänglig 19.9.2017]

Angelovska, T. (2012). Second language pronunciation : attainment and assessment. Frankfurt am Main ; New York: Peter Lang. European University Studies.

Best, C. T. (1995). A direct realist view of cross-language speech perception. I W. Strange (Red.), Speech Perception and Linguistic Experience: Issues in Cross-Language Research (s. 171-204). Timonium: York Press.

Bongaerts, T., van Summeren, C., Planken, B. \& Schils, E. (1997). Age and Ultimate Attainment in the Pronunciation of a Foreign Language. Studies in Second Language Acquisition, 19 (4), 447-465. DOI: $10.1017 / \mathrm{s} 0272263197004026$

Boyd, S. (2003). Foreign-born Teachers in the Multilingual Classroom in Sweden: The Role of Attitudes to Foreign Accent. International Journal of Bilingual Education and Bilingualism, 6 (3-4), 283-295. DOI: $10.1080 / 13670050308667786$

Crowther, D., Trofimovich, P., \& Isaacs, T. (2016). Linguistic dimensions of second language accent and comprehensibility: Nonnative listeners' perspectives. Journal of Second Language Pronunciation, 2 (2), 160-182. DOI: 10.1075/jslp.2.2.02cro

Cunningham-Andersson, U. \& Engstrand, O. (1989). Perceived strength and identity of foreign accent in Swedish. I O. Engstrand, M. Dufberg \& C. Kylander (Red.), Perilus X. Experiments in speech processes (s. 65-86). Institute of Linguistics, University of Stockholm.

Derwing, T. M. \& Munro, M. J. (2015). Pronunciation fundamentals: Evidence-based perspectives for L2 teaching and research. Amsterdam, Netherlands; Philadelphia, Pennsylvania: John Benjamins Publishing Company. DOI: $10.1075 /$ Illt.42

Derwing, T. M., Rossiter M. J., Munro, M. J. \& Thomson R. I. (2004). L2 fluency: Judgments on different tasks. Language Learning, 54 (4), 655-679. DOI: 10.1111/j.1467-9922.2004.00282.x

Eckman, F. (1977). Markedness and the contrastive analysis hypothesis. Language learning, 27 (2), 315330. DOI: 10.1111/j.1467-1770.1977.tb00124.x

Europarådet. (2001). Common European framework of reference for languages: Learning, teaching, assessment. Cambridge: Cambridge University Press.

Fayer, J. M. \& Krasinski, E. (1987). Native and nonnative judgments of intelligibility and irritation. Language Learning, 37 (3), 313-326. DOI: 10.1111/i.1467-1770.1987.tb00573.x

Flege, J. E. (1984). The detection of French accent by American listeners. Journal of the Acoustical Society of America, 76 (3), 692-707. DOI: 10.1121/1.391256 
Flege, J. E. (1987). A critical period for learning to pronounce foreign languages? Applied Linguistics, 8 (2), 162-177. DOI: $10.1093 / a p p l i n / 8.2 .162$

Flege, J. E. (1995). Second language speech learning: Theory, findings, and problems. I W. Strange (Red.), Speech Perception and Linguistic Experience. Issues in Cross-Language Research (s. 233-277). Timonium: York Press.

Flege, J. E. \& Fletcher, K. L. (1992). Talker and listener effects on degree of perceived foreign accent. Journal of the Acoustical Society of America, 91 (1), 370-389. DOI: 10.1121/1.402780

FOS 2015 = Finlands officiella statistik: Befolkningsstruktur [e-publikation]. 2015, Tabellbilaga 2. Befolkningen efter språk 1980 - 2015. Helsinki: Statistikcentralen. http://www.stat.fi/til/vaerak/2015/vaerak 2015 2016-04-01 tau 002 sv.html [Tillgänglig 21.6.2017]

Heinonen, H. \& Kautonen, M. (2017). Miten ääntämistä arvioidaan? Käytännön työkalu opettajille. Kieli, koulutus ja yhteiskunta, 8 (4). http://urn.fi/URN:NBN:fi:jyu-201709203780

Isaacs, T. \& Thomson, R. I. (2013). Rater Experience, Rating Scale Length, and Judgments of L2 Pronunciation: Revisiting Research Conventions. Language Assessment Quarterly, 10 (2), 135159. DOI: $10.1080 / 15434303.2013 .769545$

Ivars, A.-M. (2015). Dialekter och småstadsspråk. Helsingfors: Svenska litteratursällskapet i Finland.

Jesney, K. (2004). The Use of Global Foreign Accent Rating in Studies of L2 Acquisition. Calgary, AB, Canada: University of Calgary Language Research Centre Reports.

Kautonen, M. (2016). Finskspråkiga grundskoleelevers uttal av finlandssvenska på olika färdighetsnivåer. I J. Kolu, M. Kuronen \& Å. Palviainen (Red.), Svenskan i Finland 16. Jyväskylä Studies in Humanities 298 (s. 58-75). Jyväskylä: University of Jyväskylä.

Kautonen, M. (2017). Finskspråkiga talares intonation av finlandssvenska i påståendeyttranden i fritt tal. Folkmålsstudier, 55, 31-60.

Kautonen, M., Kuronen, M. Ullakonoja, R. Tergujeff, E. \& Dufva, H. (2015). På väg mot bättre språkundervisning - FOKUS på uttal. Kieli, koulutus ja yhteiskunta, 6 (1).

Kautonen, M., Kuronen, M., \& Ullakonoja, R. (2016). Studier i uttalsinlärning i finska, svenska och engelska: litteraturöversikt. Puhe ja kieli, 36 (3), 197-220.

Kennedy, S. \& Trofimovich, P. (2008). Intelligibility, comprehensibility, and accentedness of L2 speech: The role of experience and semantic context. Canadian Modern Language Review, 64 (3), 459489. DOI: $\underline{10.3138 / \mathrm{cmlr} \cdot 64.3 .459}$

Korkman, M. C. B., Green-Vänttinen, M. \& Lehti-Eklund, H. (2010). Svenska i finska gymnasier. Nordica Helsingiensia, 22 (22). Helsingfors: University of Helsinki.

Koster, C. J. \& Koet, T. (1993). The Evaluation of Accent in the English of Dutchmen. Language Learning, 43 (1), 69-92. DOI: 10.1111/j.1467-1770.1993.tb00173.x

Kuronen, M. (2015). Tonaccenterna i avancerade finska inlärares svenska - en akustisk studie. Nordand Nordisk tidsskrift for andrespråksforskning, 10 (1), 53-80.

Kuronen, M. (2016a). Avancerade finskspråkiga inlärares uttal av segment i sverigesvenska. Puhe ja kieli, 36 (3), 175-196.

Kuronen, M. (2016b). Uttal av S2-finska med fokus på svenskspråkiga talare. Puhe ja kieli, 36 (3), 147174.

Kuronen, M. \& Leinonen, K. (2001). Fonetiska skillnader mellan finlandssvenska och riksvenska. I L. Jönsson, V. Adelswärd, A. Cederberg, P. A. Pettersson \& C. Kelly (Red.), Svenskans beskrivning 24: 
Förhandlingar vid tjugofjärde sammankomsten för svenskans beskrivning, Linköping, 22-23 oktober 1999 (s. 125-138). Linköping: Linköping University Electronic Press.

Kuronen, M. \& Leinonen, K. (2010). Svenskt uttal för finskspråkiga : Teori och övningar i finlandssvenskt och rikssvenskt uttal. Tampere: Juvenes.

Kuronen, M., \& Tergujeff, E. (2018). L1 listeners' perception of L2 pronunciation: effect of prosody on accentedness ratings in Swedish. AFinLA-E: Soveltavan Kielitieteen Tutkimuksia, (10), 214-233. DOI: $10.30660 /$ afinla.73138

Kuronen, M., Ullakonoja, R. \& Kautonen, M. (2016). Inlärningen av de svenska tonaccenterna hos finska S2-talare - automatiseras uttalet? Språk och Stil NF, 26, 161-194.

Lado, R. (1957). Linguistics across cultures. Ann Arbor: University of Michigan Press.

Lehti-Eklund, H. \& Green-Vänttinen, M. (2011). Svenska i finska grundskolor. Nordica Helsingiensia, 27 (27). Helsinki: Helsingfors universitet, Finska, finskugriska och nordiska institutionen, Nordica.

Lenneberg, E. H. (1967). Biological foundations of language. New York.

Linacre, J. M. (2017). Facets (Many-Facet Rasch Measurement), Version No. 3.68.1. Beaverton: Winsteps.com. http://www.winsteps.com/facets.htm [Tillgänglig 5.10.2017]

Meister, L. \& Meister, E. (2007). Perceptual assessment of Russian-accented Estonian. ICPhS XVI : Proceedings of the 16th International Congress of Phonetic Sciences, 6-10 August 2007, Saarbrücken Germany, 1717-1720. Saarbrücken: Universität des Saarlandes.

Mennen, I. (1998). Can language learners ever acquire the intonation of a second language? Proceedings of the ESCA Workshop on Speech Technology in Language Learning, 17-20. Marholmen, Sweden.

Morris-Wilson, I. (1999). Attitudes towards Finnish-accented English. University of Stirling. http://hdl.handle.net/1893/3464

Moyer, A. (2013). Foreign accent: The phenomenon of non-native speech. Cambridge: Cambridge University Press.

Nummenmaa, L. (2009). Käyttäytymistieteiden tilastolliset menetelmät (1. rev. uppl.). Helsinki: Tammi.

Pallant J. (2005). SPSS Survival Manual: A Step by Step Guide to Data Analysis Using SPSS (2:a uppl.). Sydney: Allen and Unwin.

Peltola K. U., Tamminen H., Alku P. \& Peltola M. S. (2015). Non-native production training with an acoustic model and orthographic or transcription cues. I The Scottish Consortium for ICPhS 2015 (Red.), Proceedings of the 18th International Congress of Phonetic Sciences. Glasgow, UK: The University of Glasgow.

Piske, T., MacKay, I. \& Flege, J. (2001). Factors affecting degree of foreign accent in an L2: A review. Journal of Phonetics, 29 (2), 191-215. DOI: 10.1006/ipho.2001.0134

Rasier, L. \& Hiligsmann, P. (2007). Prosodic transfer from L1 to L2. Theoretical and methodological issues. Nouveaux cahiers de linquistique francaise, 28, 41-66. Genève: Université de Genève.

Reuter, M. (2015). Finlandssvenskt uttal. I M. Tandefelt (Red.), Gruppspråk, samspråk, två språk. Svenskan i Finland - i dag och i går l:2 (s. 19-34). Helsingfors: Svenska litteratursällskapet i Finland.

Ringen, C. \& Suomi, K. (2012). The voicing contrast in Fenno-Swedish stops. Journal of Phonetics, 40 (3), 419-429. DOI: 10.1016/i.wocn.2012.02.010

Saito, K., Trofimovich, P. \& Isaacs, T. (2017). Using listener judgements to investigate linguistic influences on L2 comprehensibility and accentedness: A validation and generalization study. Applied Linguistics, 38 (4), 439-462. DOI: 10.1093/applin/amv047 
Scovel, T. (1969). Foreign accents, language acquisition, and cerebral dominance. Language Learning, 19 (3-4), 245-253. DOI: 10.1111/j.1467-1770.1969.tb00466.x

Scovel, T. (2000). A critical review of the critical period research. Annual Review of Applied Linguistics, 20, 213-223. DOI: $10.1017 / \mathrm{s} 0267190500200135$

Shriberg, E. (2001). To 'errrr' is human: ecology and acoustics of speech disfluencies. Journal of the International Phonetic Association, 31 (1), 153-169. DOI: 10.1017/s0025100301001128

Suomi, K., Toivanen, J. \& Ylitalo, R. (2008). Finnish sound structure: Phonetics, phonology, phonotactics and prosody. Oulu: University of Oulu.

Toivola, M. (2011). Vieraan aksentin arviointi ja mittaaminen Suomessa. Helsinki: Helsingin yliopiston käyttäytymistieteiden laitos.

Trofimovich, P. \& Isaacs, T. (2012). Disentangling accent from comprehensibility. Bilingualism: Language and Cognition, 15 (4), 905-916. DOI: 10.1017/s1366728912000168

Ullakonoja, R. (2007). Comparison of Pitch Range in Finnish (L1) Fluency and Russian (L2). I J. Trouvain \& W. J. Barry (Red.), Proceedings of the 16th International Congress of Phonetic Sciences, 6-10 August 2007, Saarbrücken, Germany (s. 1701-1704).

Wrembel, M. (2010). L2-accented speech in L3 production. International Journal of Multilingualism, 7 (1), 75-90. DOI: $\underline{10.1080 / 14790710902972263}$ 